\title{
Special Issue on Organizational Training and Performance
}

\section{Charles B. Hodges ${ }^{1}$}

Published online: 4 February 2020

(C) Association for Educational Communications \& Technology 2020

This issue of the TechTrends, is a special issue guest edited by Nancy Hastings and Jennifer Bauman for the Organizational Training and Performance division of AECT. This team has put together a great issue for you; it contains 14 original papers! Their Guest Editors' Notes will provide an introduction to the issue. I appreciate all of the work they did to make this issue come together!

The issue also includes some of our regular columns. Be sure to read the Rethinking Technology \& Creativity in the 21st, Graduate Member Musings, and The History Corner. I hope you find the issue interesting!

As always, if you are interested in submitting a manuscript to TechTrends, or if you want to be a reviewer, please contact me. Encourage your colleagues to submit their work to TechTrends, to read TechTrends, and to consider joining AECT! If you have a question about the journal, my phone number is 912-478-0497 and my email address is chodges@georgiasouthern.edu. Email is always the best way to reach me. Also, you can follow TechTrends on Twitter: @AECTTechTrends.

Charles B. Hodges

chodges@georgiasouthern.edu

1 Georgia Southern University, Statesboro, GA, USA 